Review

\title{
Renewable Hydrogen Carrier - Carbohydrate: Constructing the Carbon-Neutral Carbohydrate Economy
}

\section{Y.-H. Percival Zhang ${ }^{1,2,3,4, *}$ and Jonathan R. Mielenz ${ }^{3,5}$}

1 Biological Systems Engineering Department, 210-A Seitz Hall, Virginia Polytechnic Institute and State University, Blacksburg, VA 24061, USA

2 Institute for Critical Technology and Applied Sciences (ICTAS) Virginia Polytechnic Institute and State University, Blacksburg, VA 24061, USA

3 DOE BioEnergy Science Center (BESC), Oak Ridge, TN 37831, USA;

E-Mail: mielenzjr@ornl.gov

4 Gate Fuels Inc. 3107 Alice Drive, Blacksburg, VA 24060, USA

5 Biosciences Division, Oak Ridge National Laboratory, Oak Ridge, TN 37831, USA

* Author to whom correspondence should be addressed; E-Mail: ypzhang@vt.edu; Tel.: +1-540-231-7414; Fax: +1-540-231-3199.

Received: 15 December 2010; in revised form: 8 January 2011 / Accepted: 28 January 2011 / Published: 31 January 2011

Abstract: The hydrogen economy presents an appealing energy future but its implementation must solve numerous problems ranging from low-cost sustainable production, high-density storage, costly infrastructure, to eliminating safety concern. The use of renewable carbohydrate as a high-density hydrogen carrier and energy source for hydrogen production is possible due to emerging cell-free synthetic biology technology - cell-free synthetic pathway biotransformation (SyPaB). Assembly of numerous enzymes and co-enzymes in vitro can create complicated set of biological reactions or pathways that microorganisms or catalysts cannot complete, for example, $\mathrm{C}_{6} \mathrm{H}_{10} \mathrm{O}_{5}(\mathrm{aq})+7 \mathrm{H}_{2} \mathrm{O}(\mathrm{l}) \rightarrow 12 \mathrm{H}_{2}(\mathrm{~g})+6 \mathrm{CO}_{2}(\mathrm{~g})$ (PLoS One 2007, 2:e456). Thanks to $100 \%$ selectivity of enzymes, modest reaction conditions, and high-purity of generated hydrogen, carbohydrate is a promising hydrogen carrier for end users. Gravimetric density of carbohydrate is $14.8 \mathrm{H}_{2}$ mass\% if water can be recycled from proton exchange membrane fuel cells or $8.33 \% \mathrm{H}_{2}$ mass $\%$ without water recycling. Renewable carbohydrate can be isolated from plant biomass or would be produced from a combination of solar electricity/hydrogen and carbon dioxide fixation mediated by 
high-efficiency artificial photosynthesis mediated by SyPaB. The construction of this carbon-neutral carbohydrate economy would address numerous sustainability challenges, such as electricity and hydrogen storage, $\mathrm{CO}_{2}$ fixation and long-term storage, water conservation, transportation fuel production, plus feed and food production.

Keywords: artificial photosynthesis; carbohydrate economy; carbon dioxide utilization; hydrogen carrier; hydrogen production; cell-free synthetic pathway biotransformation (SyPaB)

\section{Introduction}

The hydrogen economy is a hypothetical future energy system, where hydrogen will be used as an energy storage carrier for end users, especially in the transport sector. Electrochemist John O'M. Bockris coined the term "hydrogen economy" in his speech given at General Motors (GM) Technical Center in 1970 [1]. Two of the major advantages of the hydrogen economy are (i) much higher energy conversion efficiency from chemical energy to electricity through fuel cells compared to internal combustion engines, whose maximum efficiencies are restricted by the Second Law of thermodynamics, and (ii) nearly no pollutants generated at the sites of end users [2,3]. In addition, hydrogen can be produced by a number of approaches, and multiple energy sources from fossil fuels (e.g., natural gas, oil, coal) to renewable energy sources (e.g., biomass, solar energy, wind energy) in the future. Implementation of the hydrogen economy must address several challenges-low-cost sustainable hydrogen production, high density hydrogen storage, affordable hydrogen distribution infrastructure, durable and affordable fuel cell systems, and eliminating safety concern [4]. Among them, hydrogen storage is the most important challenge that we must solve [2-8].

For the transport sector, light-duty passenger vehicles account for $\sim 60 \%$ of transportation energy consumption in the USA [9]. Ideal transportation fuel must be stored in both high gravimetric and volumetric densities for a sufficient driving range before refilling. Gravimetric and volumetric energy densities for liquid fuels, solid fuels, hydrogen storage, and batteries are presented in Figure 1. Clearly, liquid fuels, such as diesel, gasoline, and jet fuels, are the most energy-dense fuels followed by liquid biofuels, such as biodiesel, butanol, and ethanol (Figure 1a). High energy density liquid (bio)fuels bring several advantages, such as, long travelling distance, fast refilling ( $\mathrm{MJ} / \mathrm{min})$, easy storage, and convenient distribution of liquid fuels.

Hydrogen has a very high energy density on a mass basis (143 MJ/kg) but it has very low volumetric densities because it is gas at ambient conditions. Increasing hydrogen gas pressure can improve the volumetric energy density but the weight of hydrogen containers decreases their apparent gravimetric density. For example, 350 bar and 700 bar hydrogen gas containers have gravimetric densities of 2.8-3.7 and 2.5-4.3 $\mathrm{H}_{2} \mathrm{wt} \%$, respectively (Figure $1 \mathrm{~b}$ ). The most common on-board hydrogen storage method in today's demonstration fuel cell vehicles is compressed hydrogen gas at pressures of roughly 700 bars. Also, compressing hydrogen consumes a significant fraction of hydrogen energy by about $10-17 \%$ [4]. Alternatively, hydrogen can be liquefied at $-253{ }^{\circ} \mathrm{C}$ with a volumetric density of $71 \mathrm{~kg}$ of $\mathrm{H}_{2} / \mathrm{m}^{3}$ [2]. Considering the weight of the well-insulated cryogenic 
containers, the apparent gravimetric and volumetric densities are $\sim 4.5-6.5 \mathrm{H}_{2} \mathrm{wt} \%$ and $\sim 30-40 \mathrm{~kg}$ of $\mathrm{H}_{2} / \mathrm{m}^{3}$, respectively (Figure $1 \mathrm{~b}$ ). A third approach is to absorb hydrogen into ultra-large surface solid storage materials, such as metal organic framework (MOF), nanostructured carbons (including carbon nanotubes), and clathrate hydrate [5-7,10] but their densities are not high enough (Figure 1b). Distinct from direct hydrogen storage, hydrogen can be stored as a chemical hydride, a light metal, or in a hydrogen-containing compound [2,3,6,11]. At the point of end users, hydrogen gas can be generated from their decomposition or reaction with water. In addition to their low hydrogen densities, cost-effective regeneration of hydride or light metals must be addressed.

Figure 1. Comparison of gravimetric densities and volumetric densities for liquid fuels, solid fuels, hydrogen storage means, and batteries.
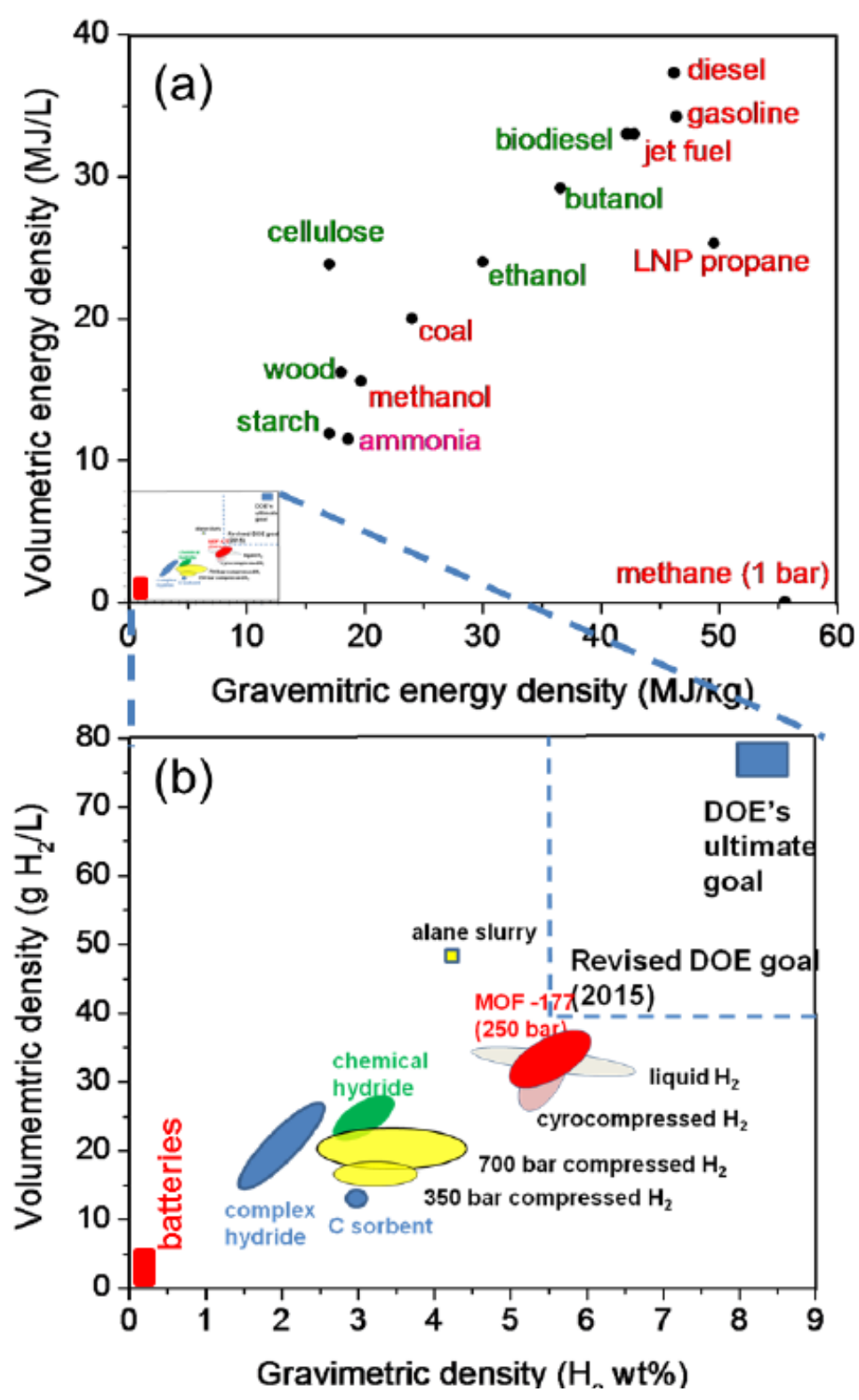

It is very challenging to find out a possible practical solution to meet the US Department of Energy's ultimate hydrogen storage goals $-\geq 8 \mathrm{H}_{2} \mathrm{wt} \%$ and $\geq 70 \mathrm{~kg}$ of $\mathrm{H}_{2} / \mathrm{m}^{3}$ (Figure $1 \mathrm{~b}$ ). To advertise and incentivize hydrogen research, the 2009-11 Hydrogen Prize will be awarded in the area of storage 
materials in mobile systems for light-duty vehicles [12]. The basic energy density requirements are $7.5 \%$ reversible $\mathrm{H}_{2}$ mass at conditions between -40 to $+85{ }^{\circ} \mathrm{C}$ and between 1.5 to 150 bars of $\mathrm{H}_{2}$ pressure and $70 \mathrm{~kg}$ of total releasable hydrogen $/ \mathrm{m}^{3}$ [3].

Another alternative to address the hydrogen storage challenges is use of high energy density hydrogen carriers, such as hydrocarbon, biodiesel, methanol, ethanol, ammonia and carbohydrate [3,13-15] (Figure 1a). But end users must have a reformer that can convert hydrogen carriers to hydrogen and purify the hydrogen stream before entering proton exchange membrane (PEM) fuel cells. The bulky size of reformers, difficult and complicated controls, plus the must need for product purification may prohibit their applications in small-size passenger vehicles [2].

Future hydrogen distribution infrastructure is closely linked with efficient hydrogen storage technology. Although natural gas and oil can be transported energy-efficiently through pipeline, it is costly for hydrogen because energy densities of compressed hydrogen based on volume is much lower than those of natural gas [16]. In addition, special pipeline materials and liners are required to avoid hydrogen embrittlement of steel. Local hydrogen stations far from a hydrogen pipeline must get the supply through hydrogen tanks, compressed hydrogen tube trailers, liquid hydrogen trailers, liquid hydrogen tank trucks or satellite on-site hydrogen producers. It is estimated that at least several hundred billions of dollars will be spent for constructing the infrastructure of the hydrogen economy based on the use of gaseous hydrogen in the US alone [17,18].

In this opinion article, we presented a new concept - the carbon-neutral carbohydrate economy based on the use of renewable carbohydrate (cellulose or starch) as a high energy density hydrogen carrier (Figure 1a), discussed great potential of the carbohydrate economy, and highlighted future R\&D priorities for its innovation.

\section{Hydrogen Production from Carbohydrate by Cell-Free Enzymatic Technology}

The production of hydrogen from low-cost renewable biomass (e.g., $\$ 60$ per dry ton or $\$ 3.60$ per GJ) [2] is appealing because biomass is an enriched, collectable chemical energy source and its production would be scalable. A number of chemical and biological approaches as well as their combinations have been investigated for the production of hydrogen from biomass carbohydrate. Chemical catalysis approaches include pyrolysis [19], gasification [20], and aqueous phase reforming [21]. All of the chemical catalysis approaches still suffer from low hydrogen yields, poor hydrogen selectivity, and poor energy efficiencies. Microbial anaerobic fermentation can produce up to four moles of hydrogen per mole of glucose along with two moles of acetate, called the Thauer limit [22]. In practice, much lower hydrogen yields (e.g., 1-3.2 moles of hydrogen per mole of glucose) are usually obtained in dark anaerobic fermentation [23-25]. Thermophilic hydrogenesis microbes can produce nearly four moles of hydrogen per glucose unit [26]. The production of hydrogen by purple bacteria or microalgae are difficult to scale up due to low energy concentration insolation (e.g., $\sim 200 \mathrm{~W} / \mathrm{m}^{2}$ ) and low photon capture densities by the cells [27]. The bioelectrochemically-assisted microbial fuel cell reactor has been shown to convert two moles of acetate to up to eight moles of hydrogen with the help of a little electricity, resulting in the overall hydrogen yields of approximately nine moles per mole of glucose [28]. A combinatorial biological and chemical catalysis is ethanol microbial 
fermentation followed by ethanol partial oxidation reforming, resulting in an overall yield of $\sim 9$ moles of hydrogen per mole of glucose [14,29].

The production of nearly 12 moles of hydrogen generated from glucose unit was a long-term dream [30]. This goal was not achieved until a new biocatalysis technology - cell-free synthetic enzymatic pathway biotransformation ( $\mathrm{SyPaB}$ ) was developed. SyPaB can implement complicated biochemical reaction networks by assembling a number of purified enzymes and coenzymes [31-33]. Microorganisms have complicated biochemical reaction network (Figure 2a) but only a small fraction of enzymes (e.g., less than 1\%) are responsible for bioconversion of a substrate to desired product while most of them are responsible for self-duplication, self-repairing, and non-product-related metabolisms. SyPaB is an open system that can be controlled and regulated easily based upon the inputs, such as temperature, substrate, pressure, and so on (Figure 2c). Breaking the cellular membrane of one microorganism and utilization of intracellular enzyme mixture for complicated biochemical reactions have been used to implement cell-free ethanol fermentation [31] or cell-free protein synthesis [34] (Figure 2b). But SyPaB has more flexibility as compared to the previous cell-free systems since we can assemble numerous enzymes from different sources and adjunct together (Figure 2c). One of the most important features of $\mathrm{SyPaB}$ can reach nearly theoretical product yields because selecting only required enzymes eliminates unnecessary pathways that consume a significant fraction of carbon and energy sources [35,36]. In addition, cell-free systems has usually much higher reaction rates than microbial fermentations because of faster mass transfer without cellular membrane and higher biocatalyst density without dilution effects from other biomacromolecules and their side reactions $[2,3,31,37,38]$.

Figure 2. System complexity comparison of in vivo microbial fermentation (a), cell-free fermentation using the cell lysate from one organism by breaking its cellular membrane (b), and cell-free synthetic enzymatic pathway biotransformation that assembles the purified stable enzymes from different organisms (c).

(a) microbial fermentation

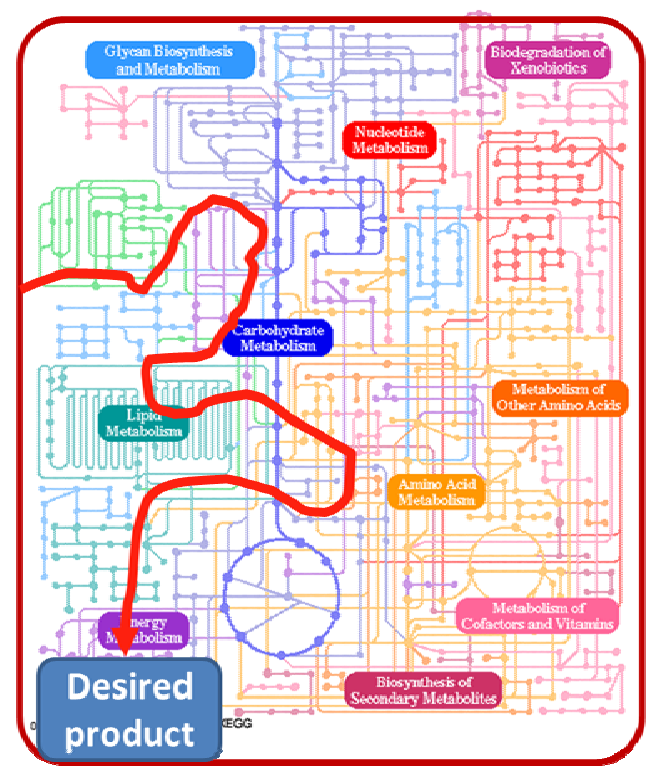

(b) cell-free fermentation

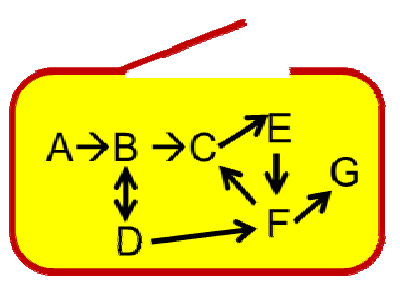

(c) cell-free SyPaB (enzyme cocktail)

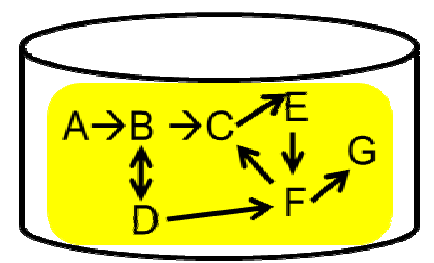


To break the Thauer limit of hydrogen-producing microbes, the synthetic enzymatic pathways have been designed to split water by using the chemical energy in carbohydrate $[39,40]$ as

$$
\mathrm{C}_{6} \mathrm{H}_{10} \mathrm{O}_{5}(\mathrm{aq})+7 \mathrm{H}_{2} \mathrm{O}(\mathrm{l}) \rightarrow 12 \mathrm{H}_{2}(\mathrm{~g})+6 \mathrm{CO}_{2}(\mathrm{~g})
$$

These non-natural synthetic catabolic pathways are comprised of 13-14 enzymes in one pot (Figure 3a). The pathways contain four biocatalytic modules: (i) a chain-shortening phosphorylation reaction for producing glucose-1-phosphate (G-1-P) catalyzed by glucan phosphorylase (Equation 2); (ii) generation of glucose-6-phosphate (G-6-P) from G-1-P catalyzed by phosphoglucomutase (Equation 3); (iii) generation of $12 \mathrm{NADPH}$ from G-6-P through a pentose phosphate pathway and some enzymes in the glycolysis and gluconeogenesis (Equation 4); and (iv) generation of hydrogen from NADPH catalyzed by NADP-dependent hydrogenase (Equation 5).

$$
\begin{aligned}
& \left(\mathrm{C}_{6} \mathrm{H}_{10} \mathrm{O}_{5}\right)_{n}+\mathrm{P}_{\mathrm{i}} \leftrightarrow\left(\mathrm{C}_{6} \mathrm{H}_{10} \mathrm{O}_{5}\right)_{n-1}+\mathrm{G}-1-\mathrm{P} \\
& \mathrm{G}-1-\mathrm{P} \leftrightarrow \mathrm{G}-6-\mathrm{P} \\
& \mathrm{G}-6-\mathrm{P}+12 \mathrm{NADP}^{+}+7 \mathrm{H}_{2} \mathrm{O} \leftrightarrow 12 \mathrm{NADPH}+12 \mathrm{H}^{+}+6 \mathrm{CO}_{2}+\mathrm{P}_{\mathrm{i}} \\
& 12 \mathrm{NADPH}+12 \mathrm{H}^{+} \leftrightarrow 12 \mathrm{H}_{2}+12 \mathrm{NADP}^{+}
\end{aligned}
$$

The entire process can be described as oxidization of glucose unit by utilization of water rather than oxygen as an electron receptor. The overall reaction (Equation 1) from polysaccharides and water is spontaneous and endothermic (i.e., $\Delta \mathrm{G}^{0}=\sim-50 \mathrm{~kJ} / \mathrm{mol}$ and $\Delta \mathrm{H}^{\circ}=+598 \mathrm{~kJ} / \mathrm{mol}$ ) [39,40]. These entropy-driven chemical reactions can generate output of chemical energy in the form of hydrogen more than the input of chemical energy in polysaccharides by absorbing ambient-temperature waste energy because of phase changes from more orderly to less orderly [39,40]. But such catabolism does not occur in any microorganism because it cannot produce any energy currency (i.e., ATP) for microorganism's growth and duplication.

When polysaccharides and water are mixed, no reaction occurs as everyone observes. When the enzyme cocktail is added, hydrogen and carbon dioxide is generated spontaneously (Figure 3b,c). Unidirectional reactions occur because the removal of gaseous products- $\mathrm{H}_{2}$ and $\mathrm{CO}_{2}$ from the aqueous phase under mild reaction conditions $\left(<100{ }^{\circ} \mathrm{C}\right.$ and $\left.\sim 1 \mathrm{~atm}\right)$. We have shown that the production rates of $\mathrm{H}_{2}$ by $\mathrm{SyPaB}$ are higher than those of photobiological systems and comparable to those reported for dark fermentations and electrohydrogensis [41,42]. It is expected that enzymatic hydrogen generation rates can be further increased greatly by several orders of magnitude for different applications in the near future $[2,3]$.

Due to essentially $100 \%$ chemical selectivity, mild reaction conditions, and high-purity hydrogen, we propose the use of renewable carbohydrates as a high-density hydrogen carrier. Polysaccharides have a chemical formula of $\mathrm{C}_{6} \mathrm{H}_{10} \mathrm{O}_{5}$ with a reaction of $\mathrm{C}_{6} \mathrm{H}_{10} \mathrm{O}_{5}(\mathrm{aq})+7 \mathrm{H}_{2} \mathrm{O}(\mathrm{l}) \rightarrow 12 \mathrm{H}_{2}(\mathrm{~g})+6 \mathrm{CO}_{2}(\mathrm{~g})$. As a result, hydrogen storage density in polysaccharides is $24 / 162=14.8 \mathrm{H}_{2}$ mass\%, when water can be recycled from PEM fuel cells. Without water recycling from fuel cells, the sugar/water slurry has a hydrogen density of $24 /(162+18 \times 7)=8.33 \% \mathrm{H}_{2}$ mass $\%$. Dry starch and amorphous cellulose have specific densities of $\sim 0.7$ and $\sim 1.4 \mathrm{~kg} / \mathrm{L}$, respectively [43]. Therefore, carbohydrates as a hydrogen carrier would meet the ultimate DOE's goals (Figure 1b). 
Figure 3. The cell-free synthetic enzymatic pathway (a), high-yield generation of hydrogen from starch (b) [40] or soluble cellodextrin (c) [39]. The enzymes are: GNP, glucan phosphorylase; PGM, phosphoglucomutase; G6PDH, G-6-P dehydrogenase; 6PGDH, 6-phosphogluconate dehydrogenase; R5PI, phosphoribose isomerase; Ru5PE, ribulose 5-phosphate epimerase; TKL, transketolase; TAL, transaldolase; TIM, triose phosphate isomerase; ALD, aldolase; FBP, fructose-1, 6-bisphosphatase; PGI, phosphoglucose isomerase; and H2ase, hydrogenase. The metabolites and chemicals are: g1p, glucose-1-phosphate; g6p, glucose-6-phosphate; 6pg, 6-phosphogluconate; ru5p, ribulose-5-phosphate; $\mathrm{x} 5 \mathrm{p}$, xylulose-5-phosphate; r5p, ribose-5-phosphate; $\mathrm{s} 7 \mathrm{p}$, sedoheptulose-7-phosphate; g3p, glyceraldehyde-3-phosphate; e4p, erythrose-4-phosphate; dhap, dihydroxacetone phosphate; fdp, fructose-1,6-diphosphate; f6p, fructose-6-phosphate; and $\mathrm{Pi}$, inorganic phosphate.
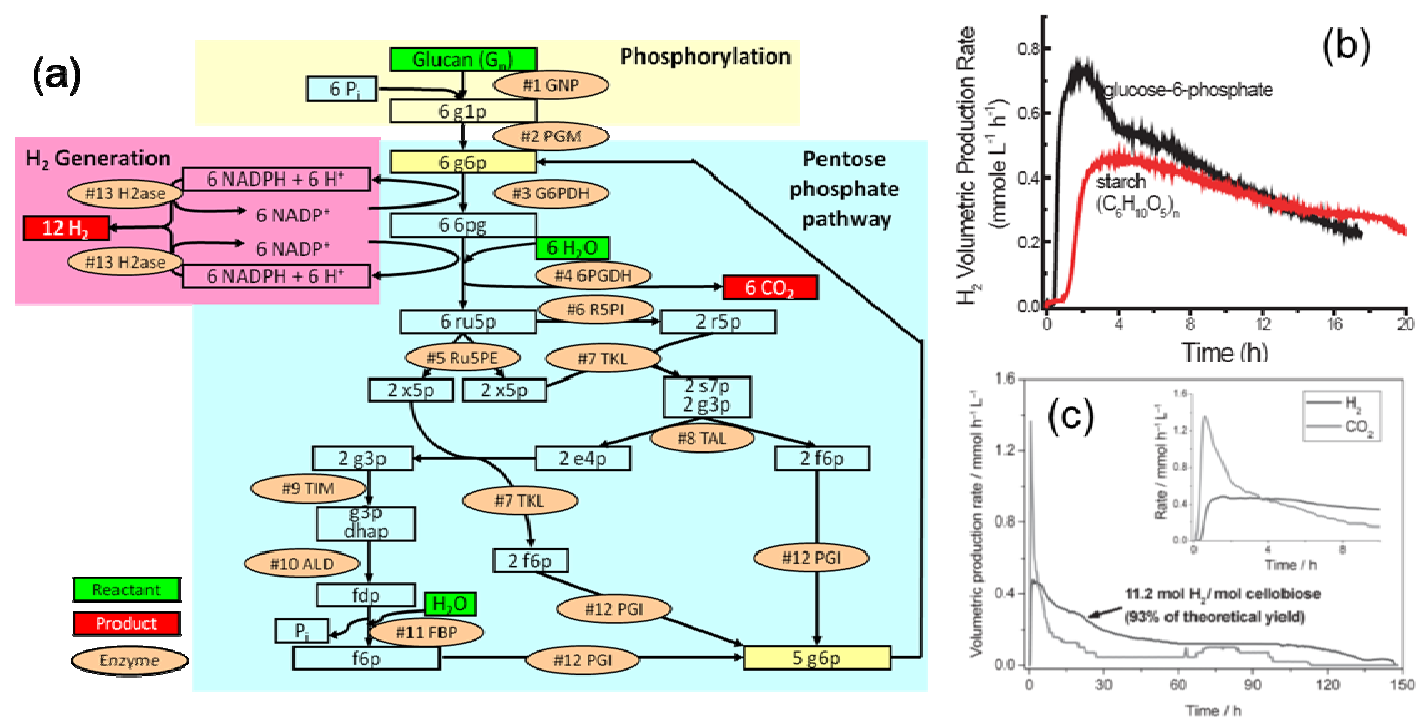

\section{The Carbon-Neutral Carbohydrate Economy}

Terrestrial plants are natural solar energy collectors that can utilize intermittent low-energy concentration solar energy and fix $\mathrm{CO}_{2}$ for the production of biomass carbohydrate. Natural photosynthesis suffers from low solar energy conversion efficiencies (4.6-6\%, theoretical; $0.2-1.0 \%$, practical) mainly due to narrow utilization of insolation spectrum (called photo-synthetically active radiation), low efficiency of carbohydrate synthesis, and respiration loss of living plants [16,44-46]. At the same time, plants consume water largely for transpiration but not for carbohydrate synthesis $[47,48]$. In spite of its low efficiency, approximately $\sim 150$ billion tons of dry phytomass is generated by terrestrial plants because plants are widely distributed and growth in large area terrestrial lands $[49,50]$. If $10 \%$ of phytobiomass (i.e., 15 billion tons of dry biomass) was utilized, we would greatly decrease our reliance on fossil fuels.

The carbon-neutral carbohydrate economy is suggested as shown in Figure 4, where carbohydrate has a central role as an energy carrier for end users. Currently carbohydrate from terrestrial plants is used as food and animal feed, sources of renewable materials (e.g., wood, paper, polylactatic acid) and liquid biofuels (e.g., ethanol and butanol), accounting for only $1.5 \%$ of NPP [51]. In the future, we 
envision that carbohydrate would have two new functions - a high-energy density hydrogen carrier and an electricity storage compound ( 11-14 MJ electricity/kg carbohydrate). For hydrogen users, the delivered solid carbohydrate or slurry can be converted to hydrogen at the points of end users for numerous applications, such as ammonia synthesis, oil refineries or biorefineries, pharmaceutical industry, or hydrogen fuel cell vehicles through local sugar-to-hydrogen stations. For high-power electricity users, carbohydrate can be converted to hydrogen followed by PEM fuel cells, such as sugar fuel cell vehicles or distributed electricity generators [3]. For low-power electricity users, sugars can be converted to electricity through enzymatic fuel cells, such as battery rechargers or portable electronics $[3,38]$.

Figure 4. The carbon-neutral carbohydrate economy linked with its current and future productions and applications.

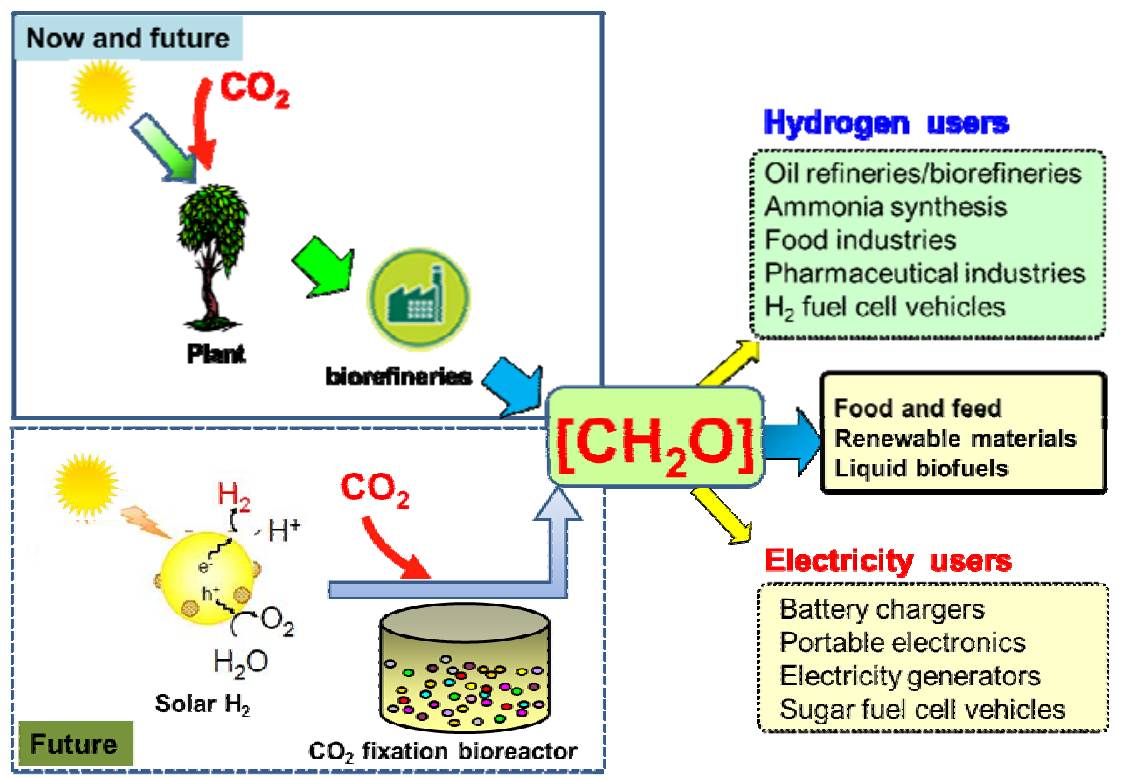

Solar energy is not really free because of the high hidden costs for its conversion, scale-up, and storage [52-54]. Efficient storage of solar electricity or solar fuel (e.g., hydrogen) on a large scale is one of the most important challenges for energy utilization, storage, and transport [55,56]. Professors Lewis and Nocera [56] suggested "store solar-converted energy in the form of chemical bonds, ... such as hydrogen, methane, methanol, or other hydrocarbon species." Here we argue that carbohydrate is a perfect energy storage compound, much better than methane, methanol, and hydrogen. To produce solar starch, we propose a scalable novel concept-artificial photosynthesis system including commercial solar cells $(\eta=\sim 18-42 \%)$, mature water electrolysis $(\eta=\sim 80-85 \%)$, or their combination - direct solar hydrogen, and a novel starch synthesis from hydrogen and carbon dioxide mediated by a non-natural cell-free synthetic enzymatic pathway $(\eta=\sim 78 \%$, projected) (Figure 4). The overall efficiency of starch synthesis from insolation could range from 12 to $28 \%$ and this system consumes only one thousandth of water of that of natural photosynthesis [46]. Implementation of the carbon-neutral carbohydrate economy would solve a number of challenges associated with sustainability, such as electricity and hydrogen storage, $\mathrm{CO}_{2}$ fixation, water conservation, transportation fuel production, feed and food production, and so on [46]. 


\section{SyPaB Challenges and Opportunities}

Modifying living organisms with new functions is difficult for several reasons while cell-free systems can be modified and controlled more easily [31-33,57]. First, living biological entities are complex open systems that operate far from thermodynamic equilibrium. Second, we can control and define the components in vitro but this operation is much harder to do in vivo. Third, it is relatively straightforward to measure rates and equilibrium constants in vitro, but these quantities are generally not easy to ascertain in vivo [58]. Fourth, the number of some types of molecules in individual cells is small and variable such that stochastic effects may dominate behavior [59]. Fifth, we can control the specificity of molecular processes in vitro by simply omitting or adding components but we know little about in vivo spatial organization of intracellular enzymes in pathways [60,61].

The prejudices that $\mathrm{SyPaB}$ is impossible for the economically viable production of low-value biofuels are attributed to a fixed paradigm in most persons' minds, resulting in a blind spot. The possible doubts include (i) enzyme instability, (ii) costly enzyme production, (iii) high cost for protein purification, (iv) high cost for protein immobilization, (v) labile costly cofactors, (vi) a lack of thermostable enzymes, (vii) complicated process operation, and (viii) high risk in scale-up.

Most enzymes in research laboratories are inactivated so rapidly that this observation leaves the impression that enzymes are not stable enough for long-time use. In reality, they may be very stable under the proper conditions by using correct enzymes, buffers, and conditions. For example, proteases in detergents have a shelf lifetime of several years at ambient temperature and keep their activities in up to $80-90{ }^{\circ} \mathrm{C}$ hot water for tens of minutes. The enzymes used in the blood sugar testing kits have a shelf lifetime of more than one year at ambient temperature. High fructose corn syrup, low-cost sucrose replacement, is made by stabilized glucose isomerase, which can work at $\sim 60{ }^{\circ} \mathrm{C}$ for even about two years [62]. We estimated that the enzyme costs would be very small when every enzyme in the SyPaB cocktails has total turn-over number (TTN) values of more than $10^{7}-10^{8}[31,33,35]$. Based on our experience and data in the literature, it is relatively easy to obtain thermoenzymes meeting with such basic TTN requirement, for example, Clostridium themocellum phosphoglucomutase (PGM) [63], C. themocellum phosphoglucose isomerase (PGI) [64], Thermotoga martima 6-phosphogluconate dehydrogenase (6PGDH) [65], T. martima fructose bisphosphatase (FBP) [66], and immobilized glucose isomerase [62].

Costly enzymes purchased from Sigma-Aldrich and other biotechnology companies (e.g., New England Biolabs) give most researchers an impression that enzymes are very costly. Also, most academic researchers know little about the advances of industrial enzymes. In reality, bulk industrial enzymes can be produced and obtained at very low costs, for example, $\sim \$ 5$ per $\mathrm{kg}$ of crude protease produced by Bacillus subtilis, $\sim \$ 10$ per $\mathrm{kg}$ of cellulase produced by Trichoderma spp., and tens of dollars per recombinant proteins produced in E. coli [67-70]. For industrial enzyme manufacturers, high-cell density fermentations are usually conducted. For example, Trichderma spp. can produce more than 100 gram of dry weight cellulase per liter of the culture [68], and Bacillus spp. can produce more than 30 gram of protease per liter of the culture [70]. But it is very difficult for academic laboratories to produce Trichoderma cellulase at even one tenth industrial levels. Systematic efforts are usually needed to increase recombinant protein expression levels. For example, expression levels of a recombinant hyperthermophilic T. maritima 6-phosphogluconate dehydrogenase in E. coli have been 
increased by $\sim 500$-fold by optimization of codon usage, expression plasmid and host, inducer type, concentration, and adding time, and so on [65]. Typical values of recombinant enzyme yield based on sugar $\left(\mathrm{Y}_{\mathrm{P} / \mathrm{S}}\right)$ may be up to $0.2 \mathrm{~g}$ of protein/g of sugar consumed [35], based on several well-known facts of (i) cell mass yield based on sugar in aerobic fermentation $\left(\mathrm{Y}_{\mathrm{X} / \mathrm{S}}\right)=\sim 0.5-0.6 \mathrm{~g}$ cell mass $/ \mathrm{g}$ sugar $[33,36,71]$, (ii) high intracellular cellular protein content $=\sim 0.5-0.6 \mathrm{~g}$ protein $/ \mathrm{g}$ cell mass [72], and (iii) high recombinant enzyme percentage in a total cellular protein $=50-70 \%[63,65,66,73]$. Based on the rule of thumb of industrial fermentations, it is estimated that the production cost of recombinant protein may be $\$ 4.50-7.5 / \mathrm{kg}$ of protein $=\$ 0.30 / \mathrm{kg}$ sugar $/(0.2 \mathrm{~g}$ protein $/ \mathrm{g}$ sugar $) \times 3-5$ (a cost adjustment coefficient due to other nutrient costs, labor, etc.).

In academic laboratory, most enzymes are purified through chromatographic techniques so that they are costly and hard to scale up. In reality, several low-cost scalable protein purification approaches are available, for example, simple centrifugation for secretory enzymes, adsorption/desorption on low-cost cellulosic materials [74,75] (Figure 5), heat precipitation for thermostable enzymes [65,76] (Figure 6), and ammonia precipitation [77] (Figure 6). Therefore, the purification costs for bulk enzymes would become relatively minor.

Figure 5. Scalable protein purification based on affinity adsorption of cellulose-binding module (CBM)-tagged protein on low-cost cellulosic absorbent followed by intein self-cleavage [74].

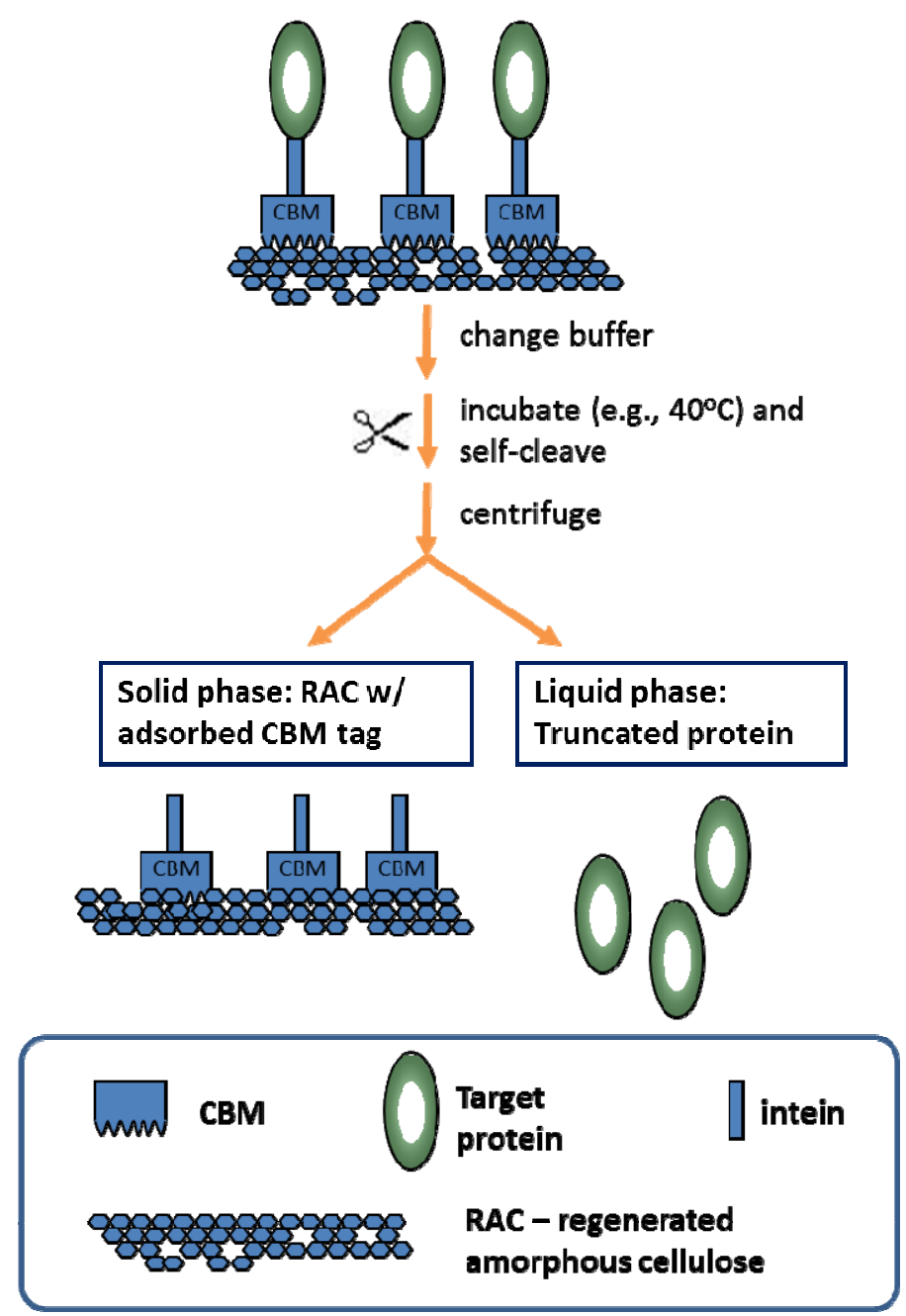


Figure 6. Simple purification of a thermoenzyme-Thermotoga maritima fructose-1,6-bisphosphate aldolase by heat precipitation and ammonia precipitation. $\mathrm{M}$, protein marker; SN, supernatant of the cell lysate; HP, the supernatant after heat precipitation; $\mathrm{SN}_{\mathrm{A}}$, the precipitate after heat treatment containing the E. coli heat-labile cellular proteins; AP, precipitated aldolase by using ammonia sulfate.

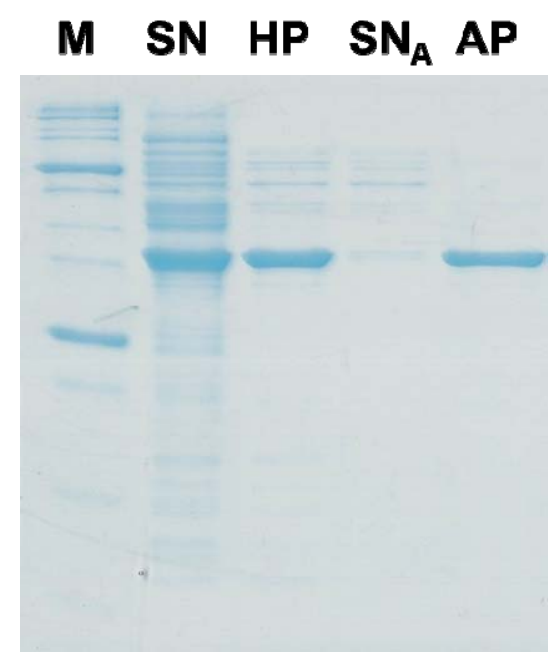

Enzyme immobilization is a relative mature industrial operation. The aforementioned example of glucose isomerase stability is only possible due to its immobilization permitting it to function at $60{ }^{\circ} \mathrm{C}$ for more than two years before it must be replaced [62]. Low-cost enzyme immobilization technologies are becoming widely-adopted, for example, cross-linking enzyme aggregate (CLEA) [78-80] and cellulose-binding module-tagged (CBM-tagged) protein immobilization [74,81-84]. The CBM-tagged enzymes can be purified and immobilized in one step, which greatly decreases processing costs and operation complexity (Figure 7).

Figure 7. One-step protein purification and immobilization of a CBM-tagged protein on a cellulosic absorbent.

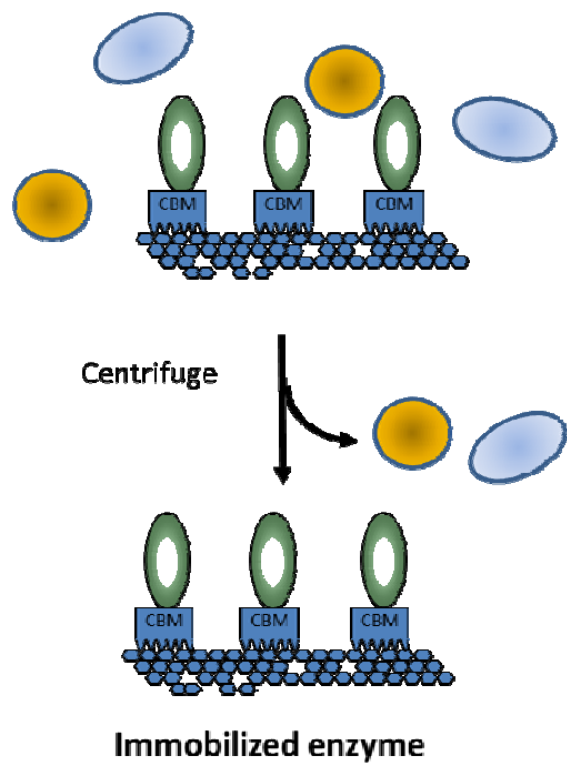


With regard to costly labile cofactors, efficient $\mathrm{NAD}(\mathrm{P}) \mathrm{H}$ recycling through immobilization of the cofactor linked to polymers has been developed [85]. The highest turn-over number (TTN) value for NAD recycling reported in the literature is $>1,000,000$ [86]. The pharmaceutical industry nearly stops further efforts in increasing TTN values of $~ 10,000-100,000$ [87,88] due to high selling values of chiral compounds plus the additional regulatory requirements if the current process is modified. But it is vital that TTN values of NAD should be higher than $10^{6}$ for the economically viable production of biocommodities [31]. Alternatively, the labile cofactor issue can be addressed by the use of low-cost more stable NAD biomimetic cofactors. But this research area is in its infancy $[89,90]$ because there has not been a sufficiently large market/product opportunity to support further R\&D before the invention of $\mathrm{SyPaB}$. Several redox enzymes have been engineered for better performance on biomimetic coenzymes [91-93].

For similar reasons, there is a lack of thermostable carbohydrate-metabolized enzymes for the $\mathrm{SyPaB}$ projects before the invention of SyPaB. Some thermostable enzymes having clear applications, such as DNA polymerases, glucose isomerases, proteases, amylases, and hemicellulases, have been exploited intensively [94-96]. Since cellulase has great potential in the production of cellulosic biofuels, several companies such as Megazyme, NZYtech are selling recombinant cellulases for research purpose. To understand crystalline structure of the proteins, Japanese scientists have undertaken the Thermus thermophiles HB8 Whole Cell Project aimed at expressing all the genes in E. coli. Consequently, more than 1400 T. thermophilus HB8 genes have been successfully over-expressed [97], but most of recombinant proteins are still not commercially available. With the fast explosion of thermophilic enzyme genomic DNA sequence databases and bioinformatics tools [98-103], the discovery of thermoenzymes is becoming a low-risk project. A combination of robotic automation and high throughput cloning makes large-size discovery of thermoenzymes feasible. In the biopharmaceutical industry, screening a large enzyme library (e.g., 500 to thousands of enzymes) for identification of one desired enzyme for the specific biocatalytic reaction is becoming a routine operation. An alternative approach for stabilizing highly-active enzymes from mesophilic sources is to use directed evolution or rational design [104-107]. Also, it is possible to let one host co-express several enzymes [37]. As a result, a combination of the enzyme cocktails from several hosts would greatly decrease fermentation burden and purification requirement. With the great potential of SyPaB technology, one might expect the construction of large library of thermoenzymes within a short time. In the future, we would expect a market to develop for numerous thermostable enzymes as basic building blocks just like purchasing computer parts, and each enzyme would have different optimal working conditions (e.g., $\mathrm{pH}$, temperature, cofactor, buffer, etc.)

$\mathrm{SyPaB}$ seems to have more complicated process operation involving protein production through microbial fermentation, cell lysis, protein purification and/or immobilization, and cocktailing (Figure $8 \mathrm{~b}$ ) as compared to microbial fermentation (Figure 8a). Although SyPaB requires protein purification and immobilization as well as cocktailing, $\mathrm{SyPaB}$ has a great advantage - a properly engineered $\mathrm{SyPaB}$ enzymatic system should function much longer (e.g., one or two orders of magnitude) than (resting-cell) microbial fermentation because each enzyme of the enzyme cocktails has been stabilized. 
Figure 8. Process complexity comparison of microbial (ethanol) fermentation involving two steps-microorganism growth and ethanol fermentation (a) and a typical SyPaB involving protein production by microbial fermentation, protein purification and/or immobilization, and biotransformation by using the stabilized enzyme mixture (b).

(a) Two-step fermentation (e.g., microbial ethanol fermentation)

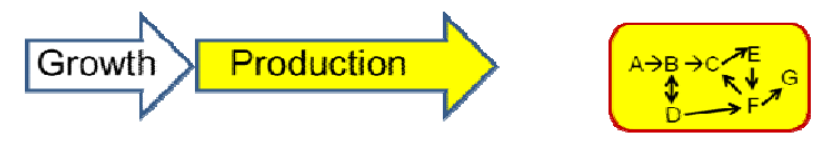

(b) Fermentation-SyPaB (e.g., enzymatic $\mathrm{H}_{2}$ production)

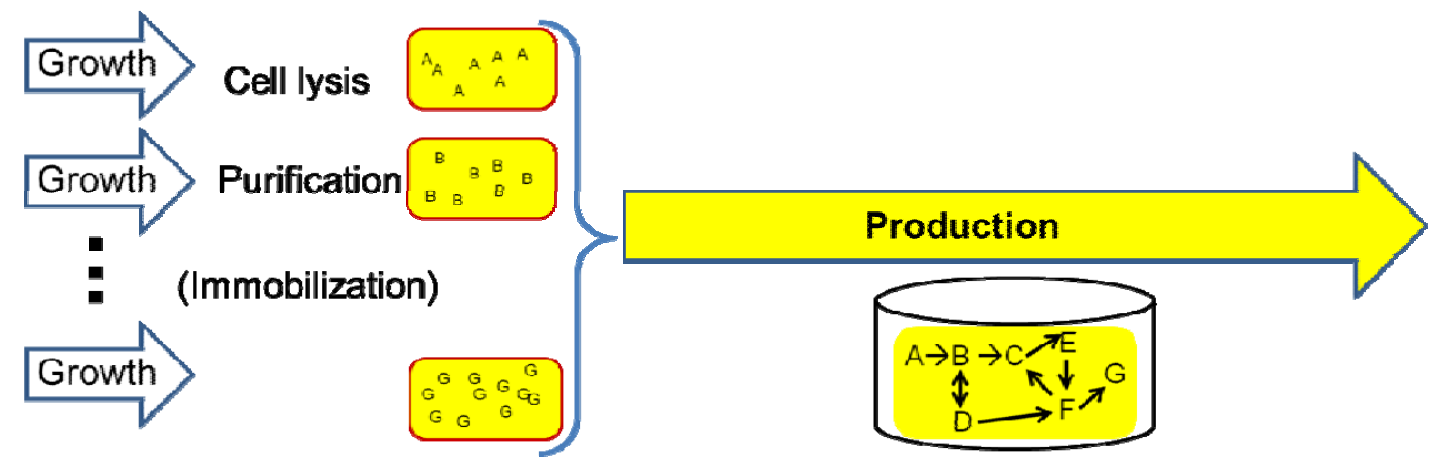

There is no obvious technical obstacle to $\mathrm{SyPaB}$ implementation because all of the recombinant enzymes, including the complicated nickel-iron hydrogenase [108], can be produced by E. coli; neither (labile) membranes nor (costly) membrane proteins are needed; neither CoA nor ATP are involved; no costly substrate is needed; the sugar-to-hydrogen reaction is conducted under strictly anaerobic conditions even when trace amount of oxygen at the beginning can be self-refreshed by the gaseous products; and low-temperature heat sources are available from PEM fuel cells or the environment.

The ultimate hydrogen production cost is estimated based on the substrate costs, catalyst costs, product separation and purification costs, and other consumable chemicals. For the production of commodities by mature technologies, the feedstock usually account for $\sim 50-80 \%$ of the final product price, for example, petroleum vs. gasoline, vegetable oil vs. biodiesel, corn kernels vs. ethanol [31,109]. Given a price of $\$ 0.18 / \mathrm{kg}$ carbohydrate (i.e., $\$ 10.6 / \mathrm{GJ}$ ) [2,44], the hydrogen production cost could range from $\$ 1.52$ to $\$ 2.43 / \mathrm{kg}$ of hydrogen based on the above rule of thumb. The detailed estimate is based on (i) $\$ 0.18 / \mathrm{kg}$ carbohydrate, (ii) all enzymes have production costs of $\$ 40$ or $\$ 400$ per $\mathrm{kg}$ of enzyme, and (iii) low-cost biomimetic cofactors used. Figure 8a shows the enzyme total turn-over number (TTN, mol product/mol enzyme) effects on hydrogen production costs. The production costs decrease rapidly with increasing TTN of the enzymes in SyPaB, and then levels off when all enzymes regardless of their production costs have TTN values of more than $10^{8-9}$. When all enzymes have TTN values of $3 \times 10^{7}$ and each one has production costs of $\sim \$ 40 / \mathrm{kg}$, hydrogen production cost is anticipated to be $\$ 1.87 / \mathrm{kg} \mathrm{H}_{2}$, where carbohydrate $(\$ 0.18 / \mathrm{kg}$ carbohydrate) accounts for approximately $65 \%$ of hydrogen production cost. When TTN values of the enzymes are further enhanced to $10^{8}$ or $10^{9}$, the ultimate cost of hydrogen would be as low as $\$ 1.30 / \mathrm{kg} \mathrm{H}_{2}$. Such hydrogen production costs by $\mathrm{SyPaB}$ would be lower than that from natural gas (e.g., $\sim \$ 2.00$ per $\mathrm{kg}$ of hydrogen). Considering potential benefits, such as nearly zero carbon footprint, evenly-distributed renewable resource, 
biohydrogen produced by $\mathrm{SyPaB}$ represents a beginning stage of low-cost, green, hydrogen production [110].

Our research showed that the gas produced by $\mathrm{SyPaB}$ contain $67 \% \mathrm{H}_{2}$ and $33 \% \mathrm{CO}_{2}[39,40]$. Hydrogen and carbon dioxide can be separated by membrane technology, pressure swing adsorption, or a hybrid of both [111]. Separation cost of $\mathrm{H}_{2}$ and $\mathrm{CO}_{2}$ is estimated to be very low [36]. Since high-purity hydrogen is mixed with an inert gas $-\mathrm{CO}_{2}$, this $\mathrm{H}_{2} / \mathrm{CO}_{2}$ mixture can be directly used by PEM fuel cells with $\sim 1 \%$ slight loss in fuel cell efficiency [36].

Figure $9 \mathrm{~b}$ shows typical TTN values of the enzymes in industrial applications and obtained in our laboratory. The relatively high cost of biomass saccharification is mainly due to very low TTN values for cellulase, for example, compared to amylase, which has at least 10-fold higher TTN values allowing amylase costs to be much lower in starch ethanol biorefineries. For industrial fructose production, ultra-stable immobilized thermophilic glucose isomerase with TTN of $\sim 10^{9}$ leads enzyme cost to a near negligible level. In our laboratory, we have obtained a few thermostable enzymes with TTN values of more than $10^{7}$, for example, C. thermocellum phosphoglucomutase [63], T. maritima fructose-1,6-bisphosphatase [66], and T. maritima 6-phosphogluconate dehydrogenase [65]. We have found out that free $C$. thermocellum phosphoglucose isomerase has low TTN values but it becomes ultra-stable (more than $10^{9}$ ) after simple immobilization through adsorption on cellulose surface by using cellulose-binding module [64], as shown in Figure 7. Clearly, it is highly operative to obtain numerous high-TTN non-membrane enzymes suitable for the SyPaB projects.

Figure 9. Cost analysis of hydrogen production in terms of TTN values of the enzymes (a) and typical total turn-over number (TTN) values of enzymes (b).

(a)

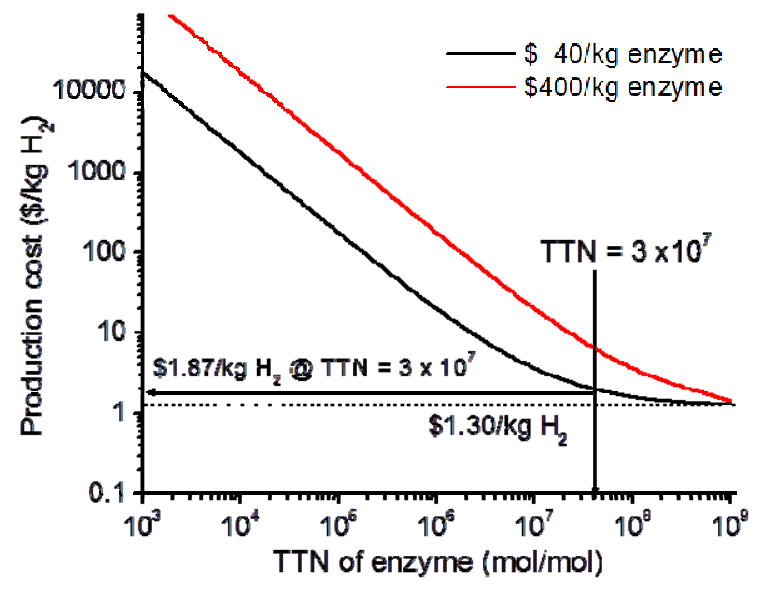

(b)

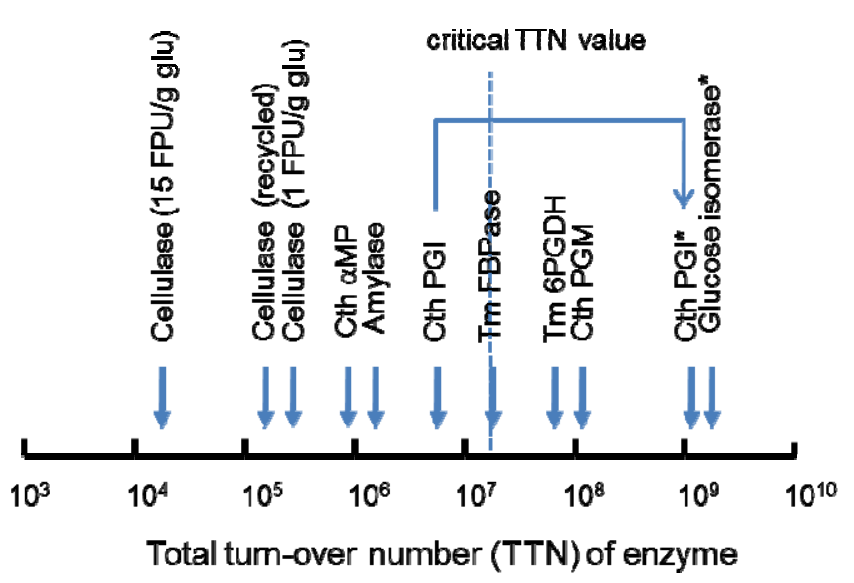

With developments in (i) engineered oxidoreductases that can use biomimetic NAD factors [91-93] and (ii) stable enzymes as building blocks of $\mathrm{SyPaB}[63,65,66,73]$, we estimate that ultimate hydrogen production costs may decrease to $\sim \$ 1.30$ per kg of hydrogen (Figure $9 \mathrm{a}$ ), where carbohydrate accounts for $\sim 95 \%$ of its production costs, in part because hydrogen has very low product separation and purification costs and the other chemicals in the reaction can be recycled. 


\section{Conclusion}

The depletion of petroleum and the concerns of climate change, national energy security, and wealth transfer are driving the world to seek alternative transportation fuel sources and increase energy utilization efficiency. Due to special requirements for the transport sector, such as high power-toweight ratio for engines, high energy storage density [2,3,36], the International Energy Agency, along with numerous experts, predicts that hydrogen fuel cell powertrain systems will become dominant, more acceptable than electric vehicles, in the future $[112,113]$. The use of renewable carbohydrate as a hydrogen storage carrier not only solves low-cost sustainable hydrogen production challenge but also address the challenges associated with storage, safety, distribution, and infrastructure in the future hydrogen economy $[2,3,40]$. International collaborative research is urgently needed to remove the remaining technical obstacles to a new carbon-neutral carbohydrate economy.

\section{Acknowledgments}

This work was supported mainly by the Air Force Office of Scientific Research, and partially by DOE Bioenergy Science Center (BESC) and USDA Biodesign and Bioprocess Center. The BioEnergy Science Center is a U.S. Department of Energy Bioenergy Research Center supported by the Office of Biological and Environmental Research in the DOE Office of Science. We appreciated the valuable suggestions and comments by Brian Davison. We also thanked Jian-Jiang Zhong for the expression plasmid encoding T. maritima fructose-1,6-bisphosphate aldolase.

\section{References}

1. Bockris, J.O.M. Energy, the Solar Hydrogen Alternative; Halsted Press: New York, NY, USA, 1975.

2. Zhang, Y.-H.P. A sweet out-of-the-box solution to the hydrogen economy: Is the sugar-powered car science fiction? Energy Environ. Sci. 2009, 2, 272-282.

3. Zhang, Y.-H.P. Renewable carbohydrates are a potential high density hydrogen carrier. Int. J. Hydrogen Energy 2010, 35, 10334-10342.

4. DOE. Basic Research Needs for the Hydrogen Economy. Available online: http://www.sc.doe.gov/bes/hydrogen.pdf (accessed on 28 January 2011).

5. Graetz, J. New approaches to hydrogen storage. Chem. Soc. Rev. 2009, 38, 73-82.

6. Orimo, S.i.; Nakamori, Y.; Eliseo, J.R.; Zuttel, A.; Jensen, C.M. Complex hydrides for hydrogen storage. Chem. Rev. 2007, 107, 4111-4132.

7. Struzhkin, V.V.; Militzer, B.; Mao, W.L.; Mao, H.k.; Hemley, R.J. Hydrogen storage in molecular clathrates. Chem. Rev. 2007, 107, 4133-4151.

8. Wang, P.; Ma, L.; Fang, Z.; Kang, X.; Wang, P. Improved hydrogen storage property of Li-MgB-H system by milling with titanium trifluoride. Energy Environ. Sci. 2009, 2, 120-123.

9. Lynd, L.R.; de Brito Cruz, C.H. Make way for ethanol. Science 2010, 330, 1176.

10. Dillon, A.C.; Heben, M.J. Hydrogen storage using carbon adsorbents: Past, present and future. Appl. Phys. A Mater. Sci. Process. 2001, 72, 133-142. 
11. Sakintuna, B.; Lamari-Darkrim, F.; Hirscher, M. Metal hydride materials for solid hydrogen storage: A review. Int. J. Hydrogen Energy 2007, 32, 1121-1140.

12. Homepage of H-prize. Available online: http://www.hydrogenprize.org/ (accessed on 28 January 2011).

13. Christensen, C.H.; Johannessen, T.; Sørensen, R.Z.; Nørskov, J.K. Towards an ammonia-mediated hydrogen economy? Catalysis Today 2006, 111, 140-144.

14. Deluga, G.A.; Salge, J.R.; Schmidt, L.D.; Verykios, X.E. Renewable hydrogen from ethanol by autothermal reforming. Science 2004, 303, 993-997.

15. Olah, G.A. Beyond Oil and Gas: The Methanol Economy. Angew. Chem. Int. Ed. 2005, 44, 2636-2639.

16. Smil, V. Energy in Nature and Society; MIT Press: Cambridge, MA, USA, 2008.

17. Moore, R.B.; Raman, V. Hydrogen infrastructure for fuel cell transportation. Int. J. Hydrogen Energy 1998, 23, 617-620.

18. Grant, P.M.; Starr, C.; Overbye, T.J. A power grid for the hydrogen economy. Sci. Am. 2006, 295, 76-83.

19. Rezaiyan, J.; Cheremisinoff, N.P. Gasification Technologies: A Primer for Engineers and Scientist; CRC press: Boca Raton, FL, USA, 2005; pp. 119-145.

20. Navarro, R.M.; Pena, M.A.; Fierro, J.L.G. Hydrogen Production Reactions from Carbon Feedstocks: Fossil Fuels and Biomass. Chem. Rev. 2007, 108, 3952-3991.

21. Cortright, R.D.; Davda, R.R.; Dumesic, J.A. Hydrogen from catalytic reforming of biomassderived hydrocarbons in liquid water. Nature 2002, 418, 964-967.

22. Thauer, K.; Jungermann, K.; Decker, K. Energy conservation in chemotrophic anaerobic bacteria. Bacteriol. Rev. 1977, 41, 100-180.

23. Adams, M.W.W.; Stiefel, E.I. Biological hydrogen production: Not so elementary. Science 1998, 282, 1842-1843.

24. Hallenbeck, P.C.; Benemann, J.R. Biological hydrogen production: Fundamentals and limiting processes. Int. J. Hydrogen Energy 2002, 27, 1185-1193.

25. Kleerebezem, R.; van Loosdrecht, M.C.M. Mixed culture biotechnology for bioenergy production. Curr. Opin. Biotechnol. 2007, 18, 207-212.

26. Chou, C.-J.; Jenney, F.E., Jr.; Adams, M.W.W.; Kelly, R.M. Hydrogenesis in hyperthermophilic microorganisms: Implications for biofuels. Metab. Eng. 2008, 10, 394-404.

27. Lardon, L.; Helias, A.; Sialve, B.; Stayer, J.P.; Bernard, O. Life-Cycle Assessment Of Biodiesel Production From Microalgae. Environ. Sci. Technol. 2009, 43, 6475-6481.

28. Logan, B.E.; Regan, J.M. Microbial fuel cells-Challenges and applications. Environ. Sci. Technol. 2006, 40, 5172-5180.

29. Haryanto, A.; Fernando, S.; Murali, N.; Adhikari, S. Current status of hydrogen production techniques by steam reforming of ethanol: A review. Energy Fuels 2005, 19, 2098-2106.

30. Chheda, J.; Huber, G.; Dumesic, J. Liquid-phase catalytic processing of biomass-derived oxygenated hydrocarbons to fuels and chemicals. Angew. Chem. Int. Ed. 2007, 46, 7164-7183.

31. Zhang, Y.-H.P. Production of biocommodities and bioelectricity by cell-free synthetic enzymatic pathway biotransformations: Challenges and opportunities. Biotechnol. Bioeng. 2010, 105, $663-677$. 
32. Zhang, Y.-H.P. Using extremophile enzymes to generate hydrogen for electricity. Microbe 2009, 4, 560-565.

33. Zhang, Y.-H.P.; Sun, J.-B.; Zhong, J.-J. Biofuel production by in vitro synthetic pathway transformation. Curr. Opin. Biotechnol. 2010, 21, 663-669.

34. Wang, Y.; Zhang, Y.-H.P. Cell-free protein synthesis energized by slowly-metabolized maltodextrin. BMC Biotechnol. 2009, 9, 58.

35. Wang, Y.; Huang, W.; Sathitsuksanoh, N.; Zhu, Z.; Zhang, Y.-H.P. Biohydrogenation from biomass sugar mediated by in vitro synthetic enzymatic pathways. Chem. Biol. 2011, accepted.

36. Huang, W.D.; Zhang, Y.-H.P. Analysis of biofuels production from sugar based on three criteria: Thermodynamics, bioenergetics, and product separation. Energy Environ. Sci. 2011, 10.1039/C0EE00069H.

37. Zehentgruber, D.; Hannemann, F.; Bleif, S.; Bernhardt, R.; Lütz, S. Towards Preparative Scale Steroid Hydroxylation with Cytochrome P450 Monooxygenase CYP106A2. ChemBioChem. 2010, 11, 713-721.

38. Cooney, M.J.; Svoboda, V.; Lau, C.; Martin, G.; Minteer, S.D. Enzyme catalysed biofuel cells. Energy Environ. Sci. 2008, 1, 320-337.

39. Ye, X.; Wang, Y.; Hopkins, R.C.; Adams, M.W.W.; Evans, B.R.; Mielenz, J.R.; Zhang, Y.-H.P. Spontaneous high-yield production of hydrogen from cellulosic materials and water catalyzed by enzyme cocktails. ChemSusChem. 2009, 2, 149-152.

40. Zhang, Y.-H.P.; Evans, B.R.; Mielenz, J.R.; Hopkins, R.C.; Adams, M.W.W. High-yield hydrogen production from starch and water by a synthetic enzymatic pathway. PLoS One 2007, 2, e456.

41. Das, D.; Veziroglu, T.N. Hydrogen production by biological processes: A survey of literature. Int. J. Hydrogen Energy 2001, 26, 13-28.

42. Cheng, S.; Logan, B.E. Sustainable and efficient biohydrogen production via electrohydrogenesis. Proc. Nat. Acad. Sci. USA 2007, 104, 18871-18873.

43. Zhang, Y.-H.P.; Lynd, L.R. Toward an aggregated understanding of enzymatic hydrolysis of cellulose: Noncomplexed cellulase systems. Biotechnol. Bioeng. 2004, 88, 797-824.

44. Zhang, Y.-H.P. Reviving the carbohydrate economy via multi-product biorefineries. J. Ind. Microbiol. Biotechnol. 2008, 35, 367-375.

45. Zhu, X.-G.; Long, S.P.; Ort, D.R. What is the maximum efficiency with which photosynthesis can convert solar energy into biomass? Curr. Opin. Biotechnol. 2008, 19, 153-159.

46. Zhang, Y.-H.P. Artificial photosynthesis would unify the electricity-carbohydrate-hydrogen cycle for sustainability. Nature Precedings 2010, 10.1038/npre.2010.4167.1.

47. Hightower, M.; Pierce, S.A. The energy challenge. Nature 2008, 452, 285-286.

48. Dominguez-Faus, R.; Powers, S.E.; Burken, J.G.; Alvarez, P.J. The Water Footprint of Biofuels: A Drink or Drive Issue? Environm. Sci. Technol. 2009, 43, 3005-3010.

49. Berner, R.A. The long-term carbon cycle, fossil fuels and atmospheric composition. Nature 2003, 426, 323-326. 
50. Falkowski, P.; Scholes, R.J.; Boyle, E.; Canadell, J.; Canfield, D.; Elser, J.; Gruber, N.; Hibbard, K.; Hogberg, P.; Linder, S.; Mackenzie, F.T.; Moore, B., III; Pedersen, T.; Rosenthal, Y.; Seitzinger, S.; Smetacek, V.; Steffen, W. The global carbon cycle: A test of our knowledge of earth as a system. Science 2000, 290, 291-296.

51. Hermann, W.A. Quantifying global exergy resources. Energy 2006, 31, 1685-1702.

52. Balzani, V.; Credi, A.; Venturi, M. Photochemical Conversion of Solar Energy. ChemSusChem. 2008, 1, 26-58.

53. Kalyanasundaram, K.; Graetzel, M. Artificial photosynthesis: Biomimetic approaches to solar energy conversion and storage. Curr. Opin. Biotechnol. 2010, 21, 298-310.

54. Lewis, N.S., Toward cost-effective solar energy use. Science 2007, 315, 798-801.

55. Gust, D.; Moore, T.A.; Moore, A.L. Solar Fuels via Artificial Photosynthesis. Acc. Chem. Res. 2009, 42, 1890-1898.

56. Lewis, N.S.; Nocera, D.G. Powering the planet: Chemical challenges in solar energy utilization. Proc. Nat. Acad. Sci. USA 2006, 103, 15729-15735.

57. Chin, J.W. Modular approaches to expanding the functions of living matter. Nat. Chem. Biol. 2006, 2, 304-311.

58. Srivastava, D.K.; Bernhard, S.A. Metabolite transfer via enzyme-enzyme complexes. Science 1986, 234, 1081-1086.

59. Taniguchi, Y.; Choi, P.J.; Li, G.-W.; Chen, H.; Babu, M.; Hearn, J.; Emili, A.; Xie, X.S. Quantifying E. coli Proteome and Transcriptome with Single-Molecule Sensitivity in Single Cells. Science 2010, 329, 533-538.

60. Conrado, R.J.; Varner, J.D.; DeLisa, M.P. Engineering the spatial organization of metabolic enzymes: Mimicking nature's synergy. Curr. Opin. Biotechnol. 2008, 19, 492-499.

61. Agapakis, C.; Ducat, D.; Boyle, P.; Wintermute, E.; Way, J.; Silver, P. Insulation of a synthetic hydrogen metabolism circuit in bacteria. J. Biol. Eng. 2010, 4, 3.

62. Vasic-Racki, D. History of industrial biotransformations-Dreams and realities. In Industrial Biotransformations; Liese, A., Seebald, S., Wandrey, C., Eds.; Wiley-VCH: Weinheim, Germany, 2006; pp 1-37.

63. Wang, Y.; Zhang, Y.-H.P. A highly active phosphoglucomutase from Clostridium thermocellum: Cloning, purification, characterization, and enhanced thermostability. J. Appl. Microbiol. 2010, 108, 39-46.

64. Myung, S.; Zhang, X.-Z.; Zhang, Y.-H.P. Ultra-stable phosphoglucose isomerase through immobilization of cellulose-binding module-tagged thermophilic enzyme on low-cost highcapacity cellulosic adsorbent. Biotechnol. Prog. 2011, submitted.

65. Wang, Y.; Zhang, Y.-H.P. Overexpression and simple purification of the Thermotoga maritima 6-phosphogluconate dehydrogenase in Escherichia coli and its application for NADPH regeneration. Microb. Cell Fact. 2009, 8, 30.

66. Myung, S.; Wang, Y.R.; Zhang, Y.-H.P. Fructose-1,6-bisphosphatase from a hyper-thermophilic bacterium Thermotoga maritima: Characterization, metabolite stability and its implications. Process Biochem. 2010, 45, 1882-1887. 
67. Taylor, L.E.I.; Dai, Z.; Decker, S.R.; Brunecky, R.; Adney, W.S.; Ding, S.-Y.; Himmel, M.E. Heterologous expression of glycosyl hydrolases in planta: A new departure for biofuels. Trends Biotechnol. 2008, 26, 413-424

68. Zhang, Y.-H.P.; Himmel, M.; Mielenz, J.R. Outlook for cellulase improvement: Screening and selection strategies. Biotechnol. Adv. 2006, 24, 452-481.

69. Sathitsuksanoh, N.; Zhu, Z.; Templeton, N.; Rollin, J.; Harvey, S.; Zhang, Y.-H.P. Saccharification of a potential bioenergy crop, Phragmites australis (common reed), by lignocellulose fractionation followed by enzymatic hydrolysis at decreased cellulase loadings. Ind. Eng. Chem. Res. 2009, 48, 6441-6447.

70. Zhang, X.-Z.; Zhang, Y.-H.P. One-step production of biocommodities from lignocellulosic biomass by recombinant cellulolytic Bacillus subtilis: Opportunities and challenges. Eng. Life Sci. 2010, 10, 398-406.

71. Shuler, M.; Kargi, F. Bioprocess Engineering: Basic Concepts, 2nd ed.; Prentice-Hall: Englewood Cliffs, NJ, USA, 2001.

72. Zhang, Y.-H.; Lynd, L.R. Quantification of cell and cellulase mass concentrations during anaerobic cellulose fermentation: Development of an ELISA-based method with application to Clostridium thermocellum batch cultures. Anal. Chem. 2003, 75, 219-227.

73. Ye, X.; Rollin, J.; Zhang, Y.-H.P. Thermophilic $\alpha$-glucan phosphorylase from Clostridium thermocellum: Cloning, Characterization and Enhanced thermostability. J. Mol. Cat. B Enzymatic 2010, 65, 110-116.

74. Hong, J.; Wang, Y.; Ye, X; Zhang, Y.-H.P. Simple protein purification through affinity adsorption on regenerated amorphous cellulose followed by intein self-cleavage. J. Chromatogr. A 2008, 1194, 150-154.

75. Hong, J.; Ye, X; Wang, Y.; Zhang, Y.-H.P. Bioseparation of recombinant cellulose binding module-protein by affinity adsorption on an ultra-high-capacity cellulosic adsorbent. Anal. Chim. Acta 2008, 621, 193-199.

76. Iyer, R.; Wang, J.; Bachas, L. Cloning, expression, and characterization of the gsdA gene encoding thermophilic glucose-6-phosphate dehydrogenase from Aquifex aeolicus. Extremophiles 2002, 6, 283-289.

77. Scopes, R.K. Protein Purification: Principles and Practice; 3rd ed.; Springer-Verleg: New York, NY, USA, 1993.

78. Cao, L.; Langen, L.V.; Sheldon, R.A. Immobilised enzymes: Carrier-bound or carrier-free? Curr. Opin. Biotechnol. 2003, 14, 387-394.

79. Mateo, C.; Palomo, J.M.; van Langen, L.M.; van Rantwijk, F.; Sheldon, R.A. A new, mild crosslinking methodology to prepare cross-linked enzyme aggregates. Biotechnol. Bioeng. 2004, 86, 273-276.

80. Sheldon, R. Cross-linked enzyme aggregates (CLEAs): Stable and recyclable biocatalysts. Biochem. Soc. Trans. 2007, 35, 1583-1587.

81. Ong, E.; Gilkes, N.R.; Warren, R.A.J.; Miller, R.C.; Kilburn, D.G. Enzyme immobilization using the cellulose-binding domain of a cellulomonas fimi exoglucanase. Nat. Biotechnol. 1989, 7 , 604-607. 
82. Tomme, P.; Boraston, A.B.; McLean, B.; Kormos, J.M.; Creagh, A.L.; Sturch, K.; Gilkes, N.R.; Haynes, C.A.; Warren, R.A.; Kilburn, D.G. Characterization and affinity applications of cellulose-binding domains. J. Chromatogr. B. 1998, 715, 283-296.

83. Shoseyov, O.; Shani, Z.; Levy, I. Carbohydrate binding modules: Biochemical properties and novel applications. Microbiol. Mol. Biol. Rev. 2006, 70, 283-295.

84. Chen, H.; Hsieh, Y.-L. Enzyme immobilization on ultrafine cellulose fibers via poly(acrylic acid) electrolyte grafts. Biotechnol. Bioeng. 2005, 90, 405-413.

85. Liu, W.; Wang, P. Cofactor regeneration for sustainable enzymatic biosynthesis. Biotechnol. Adv. 2007, 25, 369-384.

86. Kazandjian, R.; Klibanov, A. Regioselective Oxidation of Phenols Catalyzed by Polyphenol Oxidase in Chloroform. J. Am. Chem. Soc. 1985, 107, 5448-5450.

87. Moore, J.C.; Pollard, D.J.; Kosjek, B.; Devine, P.N. Advances in the enzymatic reduction of ketones. Acc. Chem. Res. 2007, 40, 1412-1419.

88. Wildeman, S.M.A.D.; Sonke, T.; Schoemaker, H.E.; May, O. Biocatalytic reductions: From lab curiosity to "first choice". Acc. Chem. Res. 2007, 40, 1260-1266.

89. Lutz, J.; Hollmann, F.; Ho, T.V.; Schnyder, A.; Fish, R.H.; Schmid, A. Bioorganometallic chemistry: Biocatalytic oxidation reactions with biomimetic $\mathrm{NAD}^{+} / \mathrm{NADH}$ co-factors and $[\mathrm{Cp} * \mathrm{Rh}(\mathrm{bpy}) \mathrm{H}]^{+}$for selective organic synthesis. J. Organomet. Chem. 2004, 689, 4783-4790.

90. Ansell, R.J.; Lowe, C.R. Artificial redox coenzymes: Biomimetic analogues of NAD ${ }^{+}$. Appl. Microbiol. Biotechnol. 1999, 51, 703-710.

91. Lo, H.C.; Fish, R.H. Biomimetic NAD ${ }^{+}$Models for Tandem Cofactor Regeneration, Horse Liver Alcohol Dehydrogenase Recognition of 1,4-NADH Derivatives, and Chiral Synthesis. Angew. Chem. Int. Ed. 2002, 41, 478-481.

92. Ryan, J.D.; Fish, R.H.; Clark, D.S. Engineering Cytochrome P450 Enzymes for Improved Activity towards Biomimetic 1,4-NADH Cofactors. ChemBioChem. 2008, 9, 2579-2582.

93. Campbell, E.; Wheeldon, I.R.; Banta, S. Broadening the cofactor specificity of a thermostable alcohol dehydrogenase using rational protein design introduces novel kinetic transient behavior. Biotechnol. Bioeng. 2010, 107, 763-774.

94. Adams, M.W.W.; Kelly, R.M. Finding and using hyperthermophilic enzymes. Trends Biotechnol. 1998, 16, 329-332.

95. Auernik, K.S.; Cooper, C.R.; Kelly, R.M. Life in hot acid: Pathway analyses in extremely thermoacidophilic archaea. Curr. Opin. Biotechnol. 2008, 19, 445-453.

96. Blumer-Schuette, S.E.; Kataeva, I.; Westpheling, J.; Adams, M.W.W.; Kelly, R.M. Extremely thermophilic microorganisms for biomass conversion: Status and prospects. Curr. Opin. Biotechnol. 2008, 19, 210-217.

97. WCPDB-Thermus thermophilus HB8 Whole Cell Project Database. Available online: http://www.srg.harima.riken.jp/ (accessed on 30 January 2011).

98. Cava, F.; Hidalgo, A.; Berenguer, J. Thermus thermophilus as biological model. Extremophiles 2009, 13, 213-231. 
99. Henne, A.; Bruggemann, H.; Raasch, C.; Wiezer, A.; Hartsch, T.; Liesegang, H.; Johann, A.; Lienard, T.; Gohl, O.; Martinez-Arias, R.; Jacobi, C.; Starkuviene, V.; Schlenczeck, S.; Dencker, S.; Huber, R.; Klenk, H.-P.; Kramer, W.; Merkl, R.; Gottschalk, G.; Fritz, H.-J. The genome sequence of the extreme thermophile Thermus thermophilus. Nat. Biotechnol. 2004, 22, 547-553.

100. Nelson, K.E.; Clayton, R.A.; Gill, S.R.; Gwinn, M.L.; Dodson, R.J.; Haft, D.H.; Hickey, E.K.; Peterson, J.D.; Nelson, W.C.; Ketchum, K.A.; McDonald, L.; Utterback, T.R.; Malek, J.A.; Linher, K.D.; Garrett, M.M.; Stewart, A.M.; Cotton, M.D.; Pratt, M.S.; Phillips, C.A.; Richardson, D.; Heidelberg, J.; Sutton, G.G.; Fleischmann, R.D.; Eisen, J.A.; White, O.; Salzberg, S.L.; Smith, H.O.; Venter, J.C.; Fraser, C.M. Evidence for lateral gene transfer between Archaea and Bacteria from genome sequence of Thermotoga maritima. Nature 1999, 399, 323-329.

101. Kawarabayasi, Y.; Sawada, M.; Horikawa, H.; Haikawa, Y.; Hino, Y.; Yamamoto, S.; Sekine, M.; Baba, S.-I.; Kosugi, H.; Hosoyama, A.; Nagai, Y.; Sakai, M.; Ogura, K.; Otsuka, R.; Nakazawa, H.; Takamiya, M.; Ohfuku, Y.; Funahashi, T.; Tanaka, T.; Kudoh, Y.; Yamazaki, J.; Kushida, N.; Oguchi, A.; Aoki, K.-I.; Yoshizawa, T.; Nakamura, Y.; Robb, F.T.; Horikoshi, K.; Masuchi, Y.; Shizuya, H.; Kikuchi, H. Complete Sequence and Gene Organization of the Genome of a Hyper-thermophilic Archaebacterium, Pyrococcus horikoshii OT3. DNA Res. 1998, 5, 55-76.

102. Bult, C.J.; White, O.; Olsen, G.J.; Zhou, L.; Fleischmann, R.D.; Sutton, G.G.; Blake, J.A.; FitzGerald, L.M.; Clayton, R.A.; Gocayne, J.D.; Kerlavage, A.R.; Dougherty, B.A.; Tomb, J.-F.; Adams, M.D.; Reich, C.I.; Overbeek, R.; Kirkness, E.F.; Weinstock, K.G.; Merrick, J.M.; Glodek, A.; Scott, J.L.; Geoghagen, N.S.M.; Weidman, J.F.; Fuhrmann, J.L.; Nguyen, D.; Utterback, T.R.; Kelley, J.M.; Peterson, J.D.; Sadow, P.W.; Hanna, M.C.; Cotton, M.D.; Roberts, K.M.; Hurst, M.A.; Kaine, B.P.; Borodovsky, M.; Klenk, H.-P.; Fraser, C.M.; Smith, H.O.; Woese, C.R.; Venter, J.C. Complete genome sequence of the methanogenic archaeon, Methanococcus jannaschii. Science 1996, 273, 1058-1073.

103. Deckert, G.; Warren, P.V.; Gaasterland, T.; Young, W.G.; Lenox, A.L.; Graham, D.E.; Overbeek, R.; Snead, M.A.; Keller, M.; Aujay, M.; Huber, R.; Feldman, R.A.; Short, J.M.; Olsen, G.J.; Swanson, R.V. The complete genome of the hyperthermophilic bacterium Aquifex aeolicus. Nature 1998, 392, 353-358.

104. Liu, W.; Hong, J.; Bevan, D.R.; Zhang, Y.-H.P. Fast identification of thermostable betaglucosidase mutants on cellobiose by a novel combinatorial selection/screening approach. Biotechnol. Bioeng. 2009, 103, 1087-1094.

105. Liu, W.; Zhang, X.-Z.; Zhang, Z.-M.; Zhang, Y.-H.P. Engineering of Clostridium phytofermentans Endoglucanase Cel5A for Improved Thermostability. Appl. Environ. Microbiol. 2010, 76, 4914-4917.

106. Arnold, F.H. Combinatorial and computational challenges for biocatalyst design. Nature 2001, 409, 253-257.

107. Zhang, X.-Z.; Zhang, Y.-H.P. Simple, fast and high-efficiency transformation system for directed evolution of cellulase in Bacillus subtilis. Microb. Biotechnol. 2011, 4, 98-105. 
108. Sun, J.; Hopkins, R.C.; Jenney, F.E.; McTernan, P.M.; Adams, M.W.W. Heterologous Expression and Maturation of an NADP-Dependent [NiFe]-Hydrogenase: A Key Enzyme in Biofuel Production. PLoS One 2010, 5, e10526.

109. Lynd, L.R.; Wyman, C.E.; Gerngross, T.U. Biocommodity engineering. Biotechnol. Prog. 1999, 15, 777-793.

110. The Royal Society of the UK Synthetic biology: Call for views. Available online: http://royalsociety.org/page.asp?changes=0\&latest=1\&id=6731 (accessed on 28 January 2011).

111. Yang, H.; Xu, Z.; Fan, M.; Gupta, R.; Slimane, R.B.; Bland, A.E.; Wright, I. Progress in carbon dioxide separation and capture: A review. J. Environ. Sci. 2008, 20, 14-27.

112. Melamu, R.; von Blottnitz, H. A comparison of environmental benefits of transport and electricity applications of carbohydrate derived ethanol and hydrogen. Int. J. Hydrogen Energy 2009, 34, 1126-1134.

113. Thomas, C.E. Fuel cell and battery electric vehicles compared. Int. J. Hydrogen Energy 2009, 34, 6005-6020.

(C) 2011 by the authors; licensee MDPI, Basel, Switzerland. This article is an open access article distributed under the terms and conditions of the Creative Commons Attribution license (http://creativecommons.org/licenses/by/3.0/). 